\section{TRIBUTE TO A GREAT DOCTOR}

Herman Boerhaave

The Man and his Work. By G. A. Lindeboom. Pp. $\mathrm{xx}+452$. (Methuen: London, November 1968.) 147s.

IT is strange that no full and authoritative life of Boerhaave has been published until now, for he was the great physician of the first half of the eighteenth century. His teaching and writings not only enhanced the fame of Leydon, but they revolutionized the whole medical teaching of Europe. For example, four of his Scottish disciples (including Dr John Rutherford, the grandfather of Sir Walter Scott) conveyed his medical teaching to Edinburgh, where Alexander Monro was already teaching anatomy and surgery on Leyden's principles, and there founded a medical school. Hence Edinburgh's medical school also became famous and the new teaching there was taken by American students to the United States. To have been a pupil of Boerhaave was a great asset in applying for any medical appointment.

Short lives of Boerhaave have been published. Samuol Johnson wrote one, unsigned, in the Gentleman's Magazine (1739); William Burton, a pupil of Boerhaave, wrote one from his lecture notes and recollections of Boerhaave (1743), as did others now to be mentioned--Mathieu Maty (1747), Jules Offray de la Mettrie (1740), and the Chevalier de Jaucourt (1751). All are based on the funeral oration on Boerhaave by his friend, Albert Schultens (1738-39, Leyden), the chief and most trustworthy source. Dr Johnson's paper is an account in English of it.

Sir Williarn Osler told me that he contemplated writing a "Life", but the plan was never fulfilled. In 1901 he spent two days at Leyden adding material to his Boerhaave collection. He spoke on Bocrhaave to the Johns Hopkins Historical Club the next autumn (unpublished). In 1918 he gave a short paper on "Boerhaave's Position in Science" (Section of History of Medicine, Royal Socicty of Medicine). The manuscript is mentioned in the Bibliotheca Osleriana, No. 7662 (1929), and then (by permission of Dr W. W. Francis, Osler Librarian, McGill University, Montreal) first published by Profossor G. A. Lindeboom in his communication, Boerhaaves Plaats in de Wetenschap (1961). Osler added Boerhaave's letters and the like to his Boerhaave collection; and before his fatal illnoss he had intended to write a short life of Boerhaave for an editor who was compiling a book of medical celebrities.

The authoritative and impressive "Life" now reviewed here has taken Professor G. A. Lindeboom fourteen years of research and then he had to write it in Dutch and English. It is well produced, with portraits of Boerhaave and other illustrations. Dr E. Ashworth Underwood has written a foreword, but, as Professor Lindeboom explains in the preface, Underwood's contribution to the English version is substantial, as otherwise it would not have appeared. Underwood has revised the English, rewriting and making additions to it, seen the book through the press and compiled the index, in constant consultation with Professor Lindeboom.

To comprehend the far-reaching influence of Boerhaave this book must be read. Herrnan Boerhaave (1668-1738) was the son of the Rev. Jacobus Boerhaave. First intended for the ministry, he studied theology and oriental languages and became a doctor of philosophy at Leyden University in 1690. Turning to medicine, he studicd anatomy, but in other subjects was largely selftaught, and graduated MD at Hardorwijk University in 1693. In 1701 he was appointed lecturer on the theory of medicine at Leyden; and in 1709 professor of medicine and of botany. In a short time he roorganized and urged an extension of the Physic Garden, published a catalogue of its plants, and was soon recognized as an eminent botanist. He was an experimental chemist for many years, isolated urea, and did research on carbon compounds and those of mercury. Osler regarded him as the founder of organic chemistry. He gave private lectures on chemistry for fifteen years which were crowded by students. In 1718 he was appointed to his third chair, professor of chemistry, and after two years gave up lecturing privately. His Elementa Chemiae (two large folio volumes, 1724) have a leading place in the history of chemistry.

Boerhaave brought in seience to the practical aid of medicine, but he insisted on the importance of studying patients at the bedside. 'This had been taught and practised at Leyden for many years. He quoted Sydenham's advice on this matter with great respect and admiration. That teaching has persisted to our time, although in some medical schools it is impaired for the medical student by too many lectures and work in laboratories.

Boerhaave's medical textbooks, now obsolcte, were used and read by three generations of medical students. His two most famous ones, Institutiones Medicae (Leyden, 1708) and Aphorismidi Cognoscendis et Curandis morbis (1709), were translated into several languages, including Arabic. He had a lucrative consulting practice.

A brilliant genius, endowed with ceaseless industry, Boerhaave was facile princeps in everything he undertook. An able teacher, an erudite lecturer and an impressive personality, he altered medical teaching for the better. This book is a worthy and permanent tribute to his memory.

Arthur MadNalty

\section{HUNTING MAN}

\section{Prehistoric Animals and their Hunters}

By I. W. Cornwall. Pp. 214. (Faber and Faber: London, 1968.) $42 s$.

IN this book Dr I. W. Cornwall sets out to give a short account of the animal environment of early man, that is, of all animals since the appearance of the first hominids nearly two million years ago. It is written for students of archaeology, anthropology, geology and geography to provide background knowledge to supplement their specialities, and for the general reader.

Because this volume is aimed at tho non-specialist reader, it was decided not to give more than a token bibliography at the end of the book: surely a detailed bibliography for each chapter could have been passed over by the general reader, but would have greatly increased the value of the book for students who would wish to pursue in much greater detail many of the subjects which are touched on. It is strange, too, that there is a marked absence in the bibliography of any books dealing with the palaeolithic and the development of hunting technology from an archaeological standpoint-one might have expected to find J. G. D. Clark's Stone Age Hunters and European Prehistory, the Economic Basis, for example.

For the benefit of the goneral reader the author has refrained from making anything more than rather general parallels to ethnographic material. Unfortunately this has resulted in some of the figures having rather bewildoring captions. How much better the caption to Fig. 3 on page 69 would have been if it had read "Ostrich-hunting by camouflage and decoy. Bushman, Africa", instead of simply "Africa, modern". Figs. 4, 9 and 13 have similarly vague captions.

The chapter headings refloct the wide range of the book: from the geological and chronological background of the Pleistocene, man's hunting techniques to the parts played by invertebrates, carnivores, elephants, Perissodactyla, Artiodactyla, Edentates and Primates in the environment of early man. For many readers the chapter on ecology, biotopes and faunal communities will be of great interest, although it is tantalizingly brief.

In the chapter on "Hunting Man" it is difficult for 